\title{
Analysis of Real and Nominal Interest Rates with Inflation for OECD Countries: Evidence from LM Unit Root Tests with Structural Breaks
}

\author{
Omer Iskenderoglu \\ Nigde University, Faculty of Economics and Administrative Sciences, \\ Nigde, 51240, TURKEY \\ Tel: 90-388-225-2458Ｅ-mail: oiskenderoglu@nigde.edu.tr
}

Received: January 16, 2011

Accepted: July 5, 2011

doi:10.5539/ijef.v3n4p130

\begin{abstract}
This paper investigates the stationary characteristics of computed real interest rates with nominal interest rates and inflation for 22 OECD countries. Using quarterly data over the $2000-2010$ period, LM unit root test is employed which endogenously determines up to two structural breaks in level and trend. The empirical findings suggest a combination of stationary and nonstationary results for real interest rates, nominal interest rates and inflation. Besides, the internal stationarity or nonstationary interactions of real and nominal interest rates are investigated by inflation. The results indicate that stationary nominal interest rates and inflation cause stationary real interest rates. At the same time nonstationary nominal interest rates and inflation could cause a stationary or nonstationary real interest rate with respect to cointegration. Stationary nominal interest rate and nonstationary real interest rate cause to nonstationary real interest rate while nonstationary nominal interest rate and stationary inflation could cause stationary or nonstationary real interest rate.
\end{abstract}

Keywords: Real interest rate, Nominal interest rate, Inflation, Structural break, Unit root

\section{Introduction}

The literature that investigates the stationary of interest rates is expanding not only with variety of methodologies but also with the purpose of studies. Since the first deductive study of Rose (1988), the body of the literature grows by time series unit root with structural breaks and panel unit root techniques. Studies which aims to search the unit root of real or nominal interest rates generally searches this for convergence, mean reversion, regime shift effects, purchasing power parity and stability of economic environment.

It is being assumed that Rose (1988) to be the first deductive study which indicates that the nominal interest rate series is not stationary. Following Rose (1988), there are many other studies investigating the unit root in nominal interest rates with time series unit root tests with or without break such as Zivot and Andrews (1992), Choi (1994), Evans and Levis (1995), Crowder and Hoffman (1996), Lumsdaine and Papell (1997), Nunes et al.(1997), Malliarapulos (2000), Newbold et al. (2001), Rapach and Weber (2004). Except the study of Malliarapulos (2000), the results indicate that nominal interest rates are unstationary. On the contrary, the results of Malliarapulos (2000) studies indicate that nominal interest rates are stationary.

Same discussions are also expanding on the real interest rates. While some of the studies indicate that real interest rates are stationary such as Garcia and Perron (1996), Clemente et al. (1998), Choi and Ahn (1999), Caporale and Grier (2000), Lai (2004); the others such as Pain (1994), Patel and Akella (1996) state that the real interest rates are nonstationary.

The literature also expands by panel econometric techniques that include panel unit root tests with structural break(s). Stationarity of nominal interest rates is tested by Costantini and Lupi (2007) for OECD countries, which indicates that nominal interest rates are stationary with breaks. Another study with structural break is realized by Arghyrou et al. (2009) which exhibits the real interest rates are stationary for 21 of 24 EMU countries.

It is possible to classify the previous studies by the ones that take into account nominal interest rate and the studies that consider real interest rate. However, Fisher (1930) links the long-run behavior of the real interest rates directly to the long-run relationship between inflation and nominal interest rates. According to this, nominal interest rates and the real interest rates could have identical behaviors. The relationship between nominal and real interest rates is defined by Fisher hypothesis which exhibits the real interest rate as the difference between the nominal rate and expected inflation. Thus, for the real interest rates to be affected only by transitory disturbances, any permanent shocks to the nominal interest rate and expected inflation must cancel out. Both inflation and nominal interest rates are affected by permanent shocks. These findings imply that nonstationary interest rates and nonstationary inflation 
is expected to result in stationary real interest rates. This is a comprehensible statement if nominal interest rates and inflation are equally affected by shocks. Thus, the common stochastic trend of nominal interest rates and inflation could be eliminated. Fisher (1930) states that cointegration would explain this result. Furthermore, without restrictive assumptions, the deductive method of Rose (1988) indicates that nonstationary nominal interest rates and stationary inflation will cause nonstationary real interest rates. Besides Costantini and Lupi (2007) indicates that if both the nominal interest rate and inflation are stationary, real interest rates should also be stationary.

There are two contributions of this paper to the existing literature. First contribution is the analysis of international data that exploits increased power deriving from the unit root methodology, together with the flexibility of allowing up to two endogenous structural breaks in the level and the trend of the individual series which is proposed by Lee and Strazicich (2003 and 2004). Second, nominal interest rates, inflation and real interest rates are all tested separately to reveal the stationary phenomenon of real interest rates by internal interaction of nominal and real interest rates.

The paper is organized as follows: the next section briefly introduces the methodology. Section 3 summarizes data and results. The last section concludes the paper.

\section{Methodology}

It is being assumed that the seminal contribution to econometric theory is the unit root process. Starting with Nelson and Plosser (1982), the literature expands by Perron (1989) which takes in to account of structural shifts. Zivot and Andrews (1992), Banerjee et al. (1992), Perron and Vogelsang (1992), Lumsdaine and Papell (1997), Perron (1997), Lee and Strazicich (2003 and 2004) are well known studies that concentrates on unit root process under structural shifts. While the methodology of Lee and Strazizich (2003 and 2004) exhibits a powerful unit root test up to two structural breaks, the results of ADF and PP Tests may be invalid if a structural break exists (Jewel et al. 2003).This paper applies univariate LM unit root tests under structural shifts which are proposed by Lee and Strazicich (2003 and 2004).

The LM unit root test considered by Lee and Strazicich (2003) originates with the estimation of two-break LM unit root test statistics. If less than two breaks is significant, the procedure is repeated using the one-break LM unit root test. If no break is significant, then the no-break LM unit-root test is employed. As such, the location of breaks, the number of breaks, and the number of lagged augmentation terms are jointly determined for each country. The steps of this procedure are also proposed by Jewel et al. (2003) and Im et al. (2005).

The first step in computing the minimum LM unit root test statistic is to compute univariate LM unit root test statistics for each country. The calculation of the univariate LM statistics with two-breaks starts with the estimation of the following equation according to LM (score) principle as follows:

$$
\Delta Y_{i t}=\delta_{i}^{\prime} \Delta Z_{i t}+\phi \widetilde{S}_{t-1}+\sum_{1}^{k} \gamma_{i} \Delta \widetilde{S}_{t-i}+\varepsilon_{t}
$$

Where $\Delta Y_{i t}$ and $\Delta Z_{i t}$ are the first differenced values of $Y_{i t}$ and $Z_{i t}$ respectively. While $Z_{i t}$ is a vector of exogenous variables defined by the data generating process where $Z_{i t}=\left[1, t, D_{1 i t}, D_{2 i t}, D T_{1 t}, D T_{2 t}\right] \cdot D_{1 i t}, D_{2 i t}$ are dummy variables that capture first and second structural break respectively. $D_{1 i t}=1$, if $\quad \mathrm{t}>$ Time Break 1, zero otherwise, $D_{2 i t}=1$ if $\quad \mathrm{t}>$ Time Break 2, zero otherwise. Besides $D T_{1 t}=\mathrm{t}-$ Time Break 1 if $\mathrm{t}>$ Time Break 1, zero otherwise, $D T_{2 t}=\mathrm{t}-$ Time Break 2 if $\mathrm{t}>$ Time Break 2, zero otherwise.

$\widetilde{S}_{t-i}$ is the detrended value of $Y_{i t-1}$, where $\widetilde{S}_{i, t}=Y_{t}-\widetilde{\psi}_{x}-Z_{t} \widetilde{\delta}$ for $\mathrm{t}=2, \ldots, \mathrm{T}$. $\widetilde{\psi}_{x}$ is given by $Y_{1}-Z_{1} \widetilde{\delta}$ where $Y_{1}$ and $Z_{1}$ are the first observations of $Y_{t}$ and $Z_{t}$ respectively. $\widetilde{\delta}$ is a vector of coefficients estimated from the regression of $\Delta Y_{i t}$ on $\Delta Y_{i t}$.

The unit root null hypothesis is described by $\phi=0$ and the LM test statistics are given by:

$$
\tilde{\tau}=t \text { Statistics for the null hypothesis } \phi=0
$$

The minimum LM unit root t-statistic determines the endogenous location of two breaks by utilizing a grid search as follows:

$$
\text { LMit }=\underset{\lambda}{\inf \tau} \tilde{\tau}(\lambda)
$$

The determination of TB is denoted by minimum LM test on equation 3 where $\lambda=\frac{T B}{T}$. 


\section{Data and Results}

The quarterly data starting from the first quarter of 2000 to last quarter of 2010 on long term nominal interest rates and inflation variables are used for 22 OECD countries (See Table 1) which obtained from OECD statistics. Long-term interest rates are the long-term government bonds that yield more than 10 years. Inflation rates are proxied by consumer price index. Following Ferreira and Leon-Ledesma (2007) and Arghyrou et al. (2009), real interest rates are computed by subtracting the inflation from nominal interest rates which is also proposed by Fisher (1930).

Countries considered in this study are Australia, Austria, Belgium, Canada, Czech Republic, Denmark, Finland, France, Germany, Greece, Hungary, Ireland, Italy, Netherlands, New Zealand, Norway, Portugal, Spain, Sweden, Switzerland, United Kingdom, and United States. The countries in the sample and the period are highly dependent to data availability.

The analysis starts with the determination of the number of augmentation terms with a maximum of $8(\mathrm{k}=8)$, and the time interval is $(0,1 ; 0,9)$ in this study. The asymptotic normal value of 1,645 , on the t-statistics of the last first differenced lagged term for $10 \%$ confidence is being used. After determination of optimal break points, each possible two combination of breaks are investigated. If the significance of the dummy coefficients is less than $10 \%$, minimum LM unit root $t$ test for one break proposed by Lee and Strazicich (2004) is applied. If the significance of the dummy coefficients are less than $10 \%$ for one break minimum LM unit root test than minimum LM unit root test without a break is employed. Optimal number of breaks denotes to structural shifts of the series (up to two). Besides optimal lag length $(\mathrm{k})$ denotes the optimal time depth of the econometric calculations. Whereas higher $(\mathrm{k})$ will lower the statistical confidence level of the results and lower (k) will conceal the coefficients. The LM unit root results of nominal interest rates, inflation and real interest rates are summarized on Table 1, Table 2 and Table 3 respectively.

The results of unit root tests in Table 1 appear to support that the nominal interest rates are nonstationary for 14 of the 22 countries. However it is possible to reject unit root null hypothesis in the cases of Australia, Austria, Czech Republic, Greece, Hungary, Italy, Switzerland, and United Kingdom. Table 1 also shows that two structural breaks are significant for two countries (Australia, United Kingdom) and 1 structural break exists in 3 countries (Austria, Czech Republic, Greece). Besides three countries have significant LM test result without break (Hungary, Italy, and Switzerland).

The results of unit root tests in Table 2 support that the inflation rates are nonstationary for 14 of 22 countries. On the other hand it is possible to reject unit root null hypothesis in the cases of Czech Republic, Greece, Hungary, Italy, Portugal, Spain, Switzerland, and United States. The number of breaks in Table 2 indicates that two structural breaks are significant only for Spain. However there are 4 countries with one significant structural break (Greece, Hungary, Portugal and Switzerland). Finally there are 3 countries that have significant LM test statistics without a break (Czech Republic, Italy and United States).

The results of unit root tests in Table 3 shows that the real interest rates are nonstationary for 8 of 22 countries. Furthermore, it is possible to reject unit root null hypothesis in the cases of Belgium, Canada Czech Republic, Finland, Greece, Hungary, Ireland, Italy, Netherlands, Norway, Portugal, Spain, Sweden, and Switzerland. Table 3 also indicates that there are 3 countries that have 2 structural breaks of real interest rates (Canada, Netherlands, Sweden) and 4 countries with 1 structural break (Greece, Italy, Portugal and Spain). There are only 7 countries that have significant LM unit root test results without a structural break (Belgium, Czech Republic, Finland, Hungary, Ireland, Norway, Switzerland).

Rose (1988) argues that, if nominal interest rates have a unit root but inflation and inflation forecast errors do not, then ex ante real interest rates have a unit root and are therefore nonstationary. Conversely it is expectable that, if inflation has a unit root and nominal interest rates do not have unit root, then ex ante real interest rates should have a unit root. While expectations are rational, actual and expected inflation will only differ by a white-noise error term (Rapach and Wohar, 2004). In other words it is reasonable to assume that ex ante and ex post inflation differ only by a stationary forecast error term. According to this thought, ex ante inflation will be in line with ex post inflation.

Another implication for the stationarity of nominal and real interest rate is stated by Costantini and Lupi (2007), which indicates that, if both the nominal interest rate and inflation are stationary, ex post real interest rates must be also stationary. Furthermore, as far as the inflation forecast errors are stationary, also ex ante real interest rates must be stationary. Another contribution on the stationarity of nominal and real interest rate is made by Crowder and Hoffman (1996), which indicates that, if the nominal interest rates and the inflation rates are both integrated of order one, stationarity of real interest rates could be obtained under several circumstances which can be explained as cointegration. One might easily argue that if both nominal interest rates and inflation are nonstationary, then real interest rates could be stationary due to the elimination of exogenous shocks and stochastic trend while calculating 
real interest rates. However this argument is valid if exogenous shocks affect the nominal interest rates and inflation proportionally at the same time. Furthermore, stochastic trend of both nominal interest rates and inflation must be identical. According to these arguments, all of the results can be summarized on Table 4 for further discussions.

Table 4 shows the stationarity results of nominal interest rates, inflation and real interest rates together. Considering the results of Table 4, real interest rates are expected to be stationary if nominal interest rates and inflation are both stationary. This eligible argument of Rose (1988) which is also considered in Costantini and Lupi (2007) can be seen for the cases of Czech Republic, Greece, Hungary, Italy and Switzerland.

Real interest rates are expected to be stationary under relevant cointegration conditions if nominal interest rates and inflation are both unstationary. The argument of Crowder and Hoffman (1996) can be seen on the cases of Belgium, Canada, Finland, Ireland, Netherlands, Norway and Sweden. However the results of Denmark, France, Germany and New Zealand shows that the nominal interest rates and inflation cannot be considered as cointegrated for the selected countries. Briefly, real interest rates could be unstationary while both nominal interest rates and inflation are nonstationary due to insufficient cointegration conditions.

While real interest rates are generated by nominal interest rates and inflation, if nominal interest rates or inflation is nonstationary, it is expected that the real interest rates would be nonstationary. This can be observed from the results of Australia, Austria and United Kingdom and United States. However, the most unexpected results are Portugal and Spain with nonstationary nominal interest rates and stationary inflation, resulting stationary real interest rates. This finding could be inconsistent with Rose (1988). However, Rose (1988) arguments are related to ex ante real interest rates, the real interest rates in this case are the ex post ones. Under the assumptions of Fisher hypothesis, the real interest rates and the inflation forecast errors are stationary and nominal interest rates are nonstationary which is also well discussed by Choi (1994). According to the results of Portugal and Spain, a stationary inflation could help to eliminate the unit root in nominal interest rates.

\section{Conclusion}

The issue of whether or not real interest rates are stationary has serious implications for researchers and policy makers. Real interest rates are result of nominal interest rates and inflation. On account of this, nominal interest rates and inflation need to be investigated simultaneously for unit root. In this paper, nominal interest rates, inflation and computed real interest rates data of 22 OECD countries are examined over the period $2000-2010$ to test for stationarity.

There are various methods that investigate unit root. However, if one or more structural breaks exist in series, an appropriate method is needed to be applied. In many economic time series, allowing for only one structural break may be too restrictive. In this study an LM unit root test that endogenously determines break in level and trend up to two structural breaks is employed. The results indicate that unit root is rejected for 14 of 22 countries. In other words, these findings provide significant evidence that real interest rates are stationary for the selected countries. This result also shows that if real interest rates are mean reverting it might be possible to forecast ex post real interest rate by using ex ante ones.

The interaction between nominal interest rates and inflation provide significant evidence for stationarity of real interest rates. First of all stationary nominal interest rates and inflation may result stationary real interest rates which is consistent with Rose (1988). Second, nonstationary interest rates and inflation could result stationary real interest rates under cointegration relationship of the series. This result is very consistent with Crowder and Hoffman (1996). The results of Portugal and Spain indicate that real interest rates could be stationary with nonstationary nominal interest rates and stationary inflation, which can be explained by Fisher hypothesis.

A different result of the study could be related with break locations. The break locations indicate a structural break on the series. However linking the actual events which results a structural break in the series may be a topic for new studies.

\section{References}

Arghyou, M.G., Gregoriou A., Kontonikas, A. (2009). Do Real Interest Rates Converge? Evidence from European Union. Journal of International Financial Markets, Institutions \& Money, (19), 447 - 460.

Banerjee, A., Lumsdaine, R. L. and Stock, J. H. (1992). Recursive and Sequential Tests of the Unit Root and Trend-Break Hypothesis: Theory and International Evidence. Journal of Business and Economic Statistics, 10, 271-287, doi:10.2307/1391542, http://dx.doi.org/10.2307/1391542

Caporale, T., Grier, K.B. (2000). Political Regime Change and The Real Interest Rate. Journal of Money, Credit and Banking, 32 (3), 320-334, doi:10.2307/1391542, http://dx.doi.org/10.2307/1391542 
Choi, S. (1994). Is The Real Interest Rate Really Unstable?. Journal of Financial Research, 17 (4), 551-559.

Choi, I., Ahn, B.C.(1999). Testing The Null Of Stationarity For Multiple Time Series. Journal of Econometrics, 88 (1), 41-77, doi:10.1016/S0304-4076(98)00021-9, http://dx.doi.org/10.1016/S0304-4076(98)00021-9

Clemente, J., Montanes, A., Reyes, M. (1998). Testing For A Unit Root in Variables With A Double Change In The Mean. Economics Letters, $59 \quad$ (2), 175-182, doi:10.1016/S0165-1765(98)00052-4, http://dx.doi.org/10.1016/S0165-1765(98)00052-4

Costantini, M.,Lupi M. (2007). An Analysis of Inflation and Interest Rates. New Panel Unit Root in The Presence of Structural Breaks. Economics Letters, 95, $408 \quad-\quad 414$, doi:10.1016/j.econlet.2006.11.016, http://dx.doi.org/10.1016/j.econlet.2006.11.016

Crowder, W.J., Hoffman, D.L. (1996). The Long-Run Relationship Between Nominal Interest Rates And Inflation: The Fisher Equation Revisited. Journal of Money, Credit and Banking, 28 (1), 102-118, doi:10.2307/2077969, http://dx.doi.org/10.2307/2077969

Evans, M.D.D., Lewis, K.K. (1995). Do Expected Shifts In Inflation Affect Estimates of The Long-Run Fisher Relation?. Journal of Finance, 50 (1), 225-253, doi:10.2307/2329244, http://dx.doi.org/10.2307/2329244

Ferreira, A.L., Leon-Ledesma, M.A. (2007). Does The Real Interest Parity Hypothesis Hold? Evidence For Developed And Emerging Markets. Journal of International Money and Finance, 26, 364-382, doi:10.1016/j.jimonfin.2006.11.003, http://dx.doi.org/10.1016/j.jimonfin.2006.11.003

Fisher, I. (1930). The Theory of Interest as Determined by Impatience to Spend Income and Opportunity to Invest It. (1930 ed.). New York: A. M. Kelley 1961.

Garcia, R., Perron, P. (1996). An Analysis Of The Real Interest Rate Under Regime Shifts. Review of Economics and Statistics, 78 (1), 111-125, doi:10.2307/2109851, http://dx.doi.org/10.2307/2109851

Im, K. S., Lee, J., and Tieslau, M. (2005). Panel Lm Unit Root Test With Level Shits. Oxford Bulletin of Economics and Statistics, 67:393-419, doi:10.1111/j.1468-0084.2005.00125.x, http://dx.doi.org/10.1111/j.1468-0084.2005.00125.x

Jewell, T., Lee, J.,Tieslau, M., Strazicich, M.C. (2003). Stationary of Health Expenditures and GDP: Evidence From Panel Unit Root Tests With Heterogeneous Structural Breaks. Journal of Health Economics, 22 (2), 313-323, doi:10.1016/S0167-6296(02)00122-4, http://dx.doi.org/10.1016/S0167-6296(02)00122-4

Lai, K.S. (2004). On Structural Shifts And Stationarity of The Ex Ante Real Interest Rate. International Review of Economics and Finance, 13 (2), 217-228, doi:10.1016/S1059-0560(03)00039-X, http://dx.doi.org/10.1016/S1059-0560(03)00039-X

Lee, J. and Strazicich, M. C. (2003). Minimum LM Unit Root Test with Two Structural Breaks. Review of Economics and Statistics, 63, 1082-1089, doi:10.1162/003465303772815961, http://dx.doi.org/10.1162/003465303772815961

Lee, J. and Strazicich, M. C. (2004). Minimum Lm Unit Root Test With One Structural Break. Appalachian State University Working Papers, 04-17, 1-15.

Lumsdaine, R.L., Papell, D.H. (1997). Multiple Trend Breaks And The Unit-Root Hypothesis. Review of Economics and Statistics. 79 (2), 212-218, doi:10.1162/003465397556791, http://dx.doi.org/10.1162/003465397556791

Malliaropulos, D. (2000). A Note on Nonstationarity, Structural Breaks, And The Fisher Effect. Journal of Banking and Finance, $24 \quad$ (5), 695-707, doi:10.1016/S0378-4266(99)00064-3, http://dx.doi.org/10.1016/S0378-4266(99)00064-3

Nelson, C. R. and Plosser C. I. (1982). Trends and Random Walks In Macroeconomic Time Series. Journal of Monetary Economics, 10, 139-162, doi:10.1016/0304-3932(82)90012-5, http://dx.doi.org/10.1016/0304-3932(82)90012-5

Newbold, P., Leybourne, S., Soleis, R.,Wohar, M.E. (2001). U.S. And U.K. Interest Rates, 1890-1934: New Evidence On Structural Breaks. Journal of Money, Credit and Banking, 33 (2), 235-250, doi:10.2307/2673883, http://dx.doi.org/10.2307/2673883

Nunes, L.C., Newbold, P., Kuan, C.-M. (1997). Testing for Unit Roots With Breaks: Evidence on The Great Crash and The Unit Root Hypothesis Reconsidered. Oxford Bulletin of Economics and Statistics, 59 (4), 435-448, doi:10.1111/1468-0084.00076, http://dx.doi.org/10.1111/1468-0084.00076

Pain, N. (1994). Monetary Policy Changes And Unit Root Statistics. Bulletin of Economic Research, 46 (2), 139-145, doi:10.1111/j.1467-8586.1994.tb00584.x, http://dx.doi.org/10.1111/j.1467-8586.1994.tb00584.x 
Patel, A., Akella, S.R. (1996). An Examination of Real Interest Rates in The United States, Canada, France and Germany During The Recent Floating Exchange Rate Period. Review of Quantitative Finance and Accounting, 6 (3), 277-292, doi:10.1007/BF00245185, http://dx.doi.org/10.1007/BF00245185

Perron, P. (1989). The Great Crash, the Oil Price Shock and the Unit Root Hypothesis. Econometrica, 57, 1361-1401, doi:10.2307/1913712, http://dx.doi.org/10.2307/1913712

Perron, P. (1997). Further Evidence on Breaking Trend Functions in Macroeconomic Variables. Journal of Econometrics, $\quad 80 \quad$ (2), 355-385, doi:10.1016/S0304-4076(97)00049-3, http://dx.doi.org/10.1016/S0304-4076(97)00049-3

Perron, P. and Vogelsang, T. J. (1992). Nonstationarity and Level Shifts With an Application to Purchasing Power Parity. Journal of Business and Economic Statistics, 10, 301-320, doi:10.2307/1391544, http://dx.doi.org/10.2307/1391544

Rapach, D.E.,Weber, C.E. (2004). Are Real Interest Rates Really Nonstationary. New Evidence From Tests With Good Size And Power?. Journal of Macroeconomics, 26 (3), 409-430, doi:10.1016/j.jmacro.2003.03.001, http://dx.doi.org/10.1016/j.jmacro.2003.03.001

Rapach, D. E., and Wohar, M. E. (2004). The Persistence in International Real Interest Rates. International Journal of Finance and Economics, 9, 339-346, doi:10.1002/ijfe.254, http://dx.doi.org/10.1002/ijfe.254

Rose, A.K., (1988). Is The Real Interest Rate Stable?. Journal of Finance, 43 (5), 1095-1112, doi:10.2307/2328208, http://dx.doi.org/10.2307/2328208

Zivot, E., Andrews, D.W.K.,(1992). Further Evidence on The Great Crash, The Oil-Price Shock, and The Unit-Root Hypothesis. Journal of Business and Economic Statistics, 10 (3), 251-270, doi:10.1016/S0304-4076(97)00049-3, http://dx.doi.org/10.1016/S0304-4076(97)00049-3

Table 1. LM unit root tests on nominal interest rates

\begin{tabular}{|l|l|l|l|r|}
\hline Country & $\begin{array}{l}\text { Univariate LM unit root test } \\
\text { statistics }\end{array}$ & Optimal \# of breaks & $\begin{array}{l}\text { Optimal lag length } \\
(\mathrm{k})\end{array}$ & Break Location(s) \\
\hline Australia & $-7,198^{*}$ & 2 & 6 & $2007 \mathrm{Q} 4,2008 \mathrm{Q} 4$ \\
\hline Austria & $-3,563^{* * *}$ & 1 & 0 & $2005 \mathrm{Q} 2$ \\
\hline Belgium & $-2,700$ & 1 & 8 & $2005 \mathrm{Q} 2$ \\
\hline Canada & $-1,105$ & 0 & 8 & - \\
\hline Czech Rep. & $-3,727^{* *}$ & 1 & 5 & $2005 \mathrm{Q} 2$ \\
\hline Denmark & $-3,230$ & 2 & 7 & $2005 \mathrm{Q} 2,2007 \mathrm{Q} 4$ \\
\hline Finland & $-2,441$ & 1 & 7 & $2005 \mathrm{Q} 2$ \\
\hline France & $-3,126$ & 1 & 0 & $2005 \mathrm{Q} 2$ \\
\hline Germany & $-2,921$ & 1 & 0 & $2005 \mathrm{Q} 2$ \\
\hline Greece & $-3,439^{* *}$ & 1 & 0 & $2005 \mathrm{Q} 2$ \\
\hline Hungary & $-3,493^{* *}$ & 0 & 8 & - \\
\hline Ireland & $-2,118$ & 1 & 0 & $2005 \mathrm{Q} 2$ \\
\hline Italy & $-4,323^{* * *}$ & 0 & 0 & - \\
\hline Netherlands & $-3,076$ & 1 & 0 & $2005 \mathrm{Q} 2$ \\
\hline New Zealand & $-1,723$ & 0 & 7 & - \\
\hline Norway & $-2,145$ & 1 & 3 & $2005 \mathrm{Q} 2$ \\
\hline Portugal & $-3,057$ & 2 & 8 & $2005 \mathrm{Q} 2,2007 \mathrm{Q} 4$ \\
\hline Spain & $-0,671$ & 0 & 0 & - \\
\hline Sweden & $-2,969$ & 0 & 3 & $2005 \mathrm{Q} 2$ \\
\hline Switzerland & $-4,039^{* * *}$ & $-7,232^{*}$ & 0 & - \\
\hline United Kingdom & $-1,992$ & 0 & - \\
\hline United States & 0 & $2004 \mathrm{Q} 2,2005 \mathrm{Q} 4$ \\
\hline
\end{tabular}

All tests allow for time fixed effects and all regressions include an intercept and time trend. Structural breaks denote a shift in the level or intercept.

The 1,5 and $10 \%$ critical values for the LM unit root test with no break are: $-3,63,-3,06$ and $-2,77$.

The 1,5 , and $10 \%$ critical values for the minimum LM test with one break are: $-4,239,-3,566$, and $-3,211$.

The 1,5 , and $10 \%$ critical values for the minimum LM test with two breaks are: $-4,545,-3,842$, and $-3,504$.

$*, * *, \quad * * *$ denote statistical significance at the $1 \%, 5 \%, 10 \%$ levels. 
Table 2. LM unit root tests on inflation

\begin{tabular}{|l|l|l|l|r|}
\hline Country & Univariate LM Unit Root Test Statistics & Optimal \# of Breaks & Optimal Lag Length & Break Location(s) \\
\hline Australia & $-3,255$ & 2 & 8 & $2003 Q 2,2008 \mathrm{Q} 3$ \\
\hline Austria & $-1,861$ & 1 & 3 & $2007 \mathrm{Q} 3$ \\
\hline Belgium & $-2,585$ & 1 & 8 & $2008 \mathrm{Q} 2$ \\
\hline Canada & $-3,238$ & 2 & 8 & $2003 \mathrm{Q} 2,2007 \mathrm{Q} 3$ \\
\hline Czech Rep. & $-8,234^{*}$ & 0 & 1 & - \\
\hline Denmark & $-0,307$ & 0 & 8 & - \\
\hline Finland & $-1,988$ & 0 & 4 & - \\
\hline France & $-1,118$ & 0 & 4 & - \\
\hline Germany & $-2,594$ & 1 & 5 & $2007 \mathrm{Q} 4$ \\
\hline Greece & $-4,017^{* *}$ & 1 & 6 & $2007 \mathrm{Q} 1$ \\
\hline Hungary & $-4,366^{*}$ & 1 & 0 & $2006 \mathrm{Q} 4$ \\
\hline Ireland & $-2,677$ & 1 & 8 & $2005 \mathrm{Q} 4$ \\
\hline Italy & $-4,883^{*}$ & 0 & 6 & - \\
\hline Netherlands & $-2,956$ & 5 & $2005 \mathrm{Q} 1,2005 \mathrm{Q} 4$ \\
\hline New Zealand & $-1,900$ & 2 & 3 & - \\
\hline Norway & $-3,180$ & 0 & 3 & $2002 \mathrm{Q} 3,2008 \mathrm{2} 1$ \\
\hline Portugal & $-6,438^{*}$ & 2 & 1 & $2004 \mathrm{Q} 3$ \\
\hline Spain & $-3,505^{* * *}$ & 1 & 6 & $2002 \mathrm{Q} 3,2008 \mathrm{2} 1$ \\
\hline Sweden & $-1,365$ & 2 & 3 & - \\
\hline Switzerland & $-7,323^{*}$ & 0 & 1 & $2007 \mathrm{2}$ \\
\hline United Kingdom & $-0,424$ & 0 & 7 & - \\
\hline United States & $-2,833^{* * *}$ & 1 & - & - \\
\hline
\end{tabular}

All tests allow for time fixed effects and all regressions include an intercept and time trend. Structural breaks denote a shift in the level or intercept.

The 1,5 and $10 \%$ critical values for the LM unit root test with no break are: $-3,63,-3,06$ and $-2,77$.

The 1,5 , and $10 \%$ critical values for the minimum LM test with one break are: $-4,239,-3,566$, and $-3,211$.

The 1,5 , and $10 \%$ critical values for the minimum LM test with two breaks are: $-4,545,-3,842$, and $-3,504$.

$*, * *, \quad * * *$ denote statistical significance at the $1 \%, 5 \%, 10 \%$ levels.

Table 3. LM unit root tests on real interest rate

\begin{tabular}{|c|c|c|c|c|}
\hline Country & Univariate LM Unit Root Test Statistics & Optimal \# of Breaks & Optimal Lag Length & Break Location(s) \\
\hline Australia & $-1,311$ & 0 & 3 & - \\
\hline Austria & $-1,320$ & 0 & 4 & - \\
\hline Belgium & $-6,306^{*}$ & 0 & 1 & - \\
\hline Canada & $-3,537 * *$ & 2 & 0 & 2004Q3, 2009Q4 \\
\hline Czech Rep. & $-2,878 * * *$ & 0 & 5 & - \\
\hline Denmark & $-2,273$ & 1 & 4 & 2008Q1 \\
\hline Finland & $-6,398^{*}$ & 0 & 1 & - \\
\hline France & $-1,385$ & 0 & 1 & - \\
\hline Germany & $-2,098$ & 0 & 5 & - \\
\hline Greece & $-6,909 *$ & 1 & 0 & 2003Q4 \\
\hline Hungary & $-6,207 *$ & 0 & 1 & - \\
\hline Ireland & $-6,196^{*}$ & 0 & 1 & - \\
\hline Italy & $-6,946^{*}$ & 1 & 1 & 2003Q4 \\
\hline Netherlands & $-5,752 *$ & 2 & 0 & 2002Q4, 2006Q4 \\
\hline New Zealand & $-0,554$ & 0 & 8 & - \\
\hline Norway & $-6,762 *$ & 0 & 1 & - \\
\hline Portugal & $-5,410^{*}$ & 1 & 0 & 2008Q2 \\
\hline Spain & $-6,303 *$ & 1 & 1 & 2006Q1 \\
\hline Sweden & $-5,448 *$ & 2 & 0 & 2002Q4, 2007Q4 \\
\hline Switzerland & $-3,100 * *$ & 0 & 3 & - \\
\hline United Kingdom & $-2,298$ & 0 & 6 & - \\
\hline United States & $-2,571$ & 1 & 3 & 2003Q1 \\
\hline
\end{tabular}

All tests allow for time fixed effects and all regressions include an intercept and time trend. Structural breaks denote a shift in the level or intercept.

The 1,5 and $10 \%$ critical values for the LM unit root test with no break are: $-3,63,-3,06$ and $-2,77$.

The 1,5 , and $10 \%$ critical values for the minimum LM test with one break are: $-4,239,-3,566$, and $-3,211$.

The 1,5 , and $10 \%$ critical values for the minimum LM test with two breaks are: $-4,545,-3,842$, and $-3,504$.

$*, * *, \quad * * *$ denote statistical significance at the $1 \%, 5 \%, 10 \%$ levels. 
Table 4. Summary of the Stationary Results of Nominal interest rates, inflation, real interest rates

\begin{tabular}{|l|l|l|l|}
\hline Country & \multicolumn{1}{|c|}{ Nominal Interest Rate } & \multicolumn{1}{c|}{ Inflation } & \multicolumn{1}{c|}{ Real Interest rate } \\
\hline Australia & Stationary & Nonstationary & Nonstationary \\
\hline Austria & Stationary & Nonstationary & Nonstationary \\
\hline Belgium & Nonstationary & Nonstationary & Stationary \\
\hline Canada & Nonstationary & Nonstationary & Stationary \\
\hline Czech Rep. & Stationary & Stationary & Stationary \\
\hline Denmark & Nonstationary & Nonstationary & Nonstationary \\
\hline Finland & Nonstationary & Nonstationary & Stationary \\
\hline France & Nonstationary & Nonstationary & Nonstationary \\
\hline Germany & Nonstationary & Nonstationary & Nonstationary \\
\hline Greece & Stationary & Stationary & Stationary \\
\hline Hungary & Stationary & Stationary & Stationary \\
\hline Ireland & Nonstationary & Nonstationary & Stationary \\
\hline Italy & Stationary & Stationary & Stationary \\
\hline Netherlands & Nonstationary & Nonstationary & Stationary \\
\hline New Zealand & Nonstationary & Nonstationary & Nonstationary \\
\hline Norway & Nonstationary & Nonstationary & Stationary \\
\hline Portugal & Nonstationary & Stationary & Stationary \\
\hline Spain & Nonstationary & Stationary & Stationary \\
\hline Sweden & Nonstationary & Nonstationary & Stationary \\
\hline Switzerland & Stationary & Stationary & Stationary \\
\hline United Kingdom & Stationary & Nonstationary & Nonstationary \\
\hline United States & Nonstationary & Stationary & Nonstationary \\
\hline & & & \\
\hline
\end{tabular}

